\title{
Redescription of Charaxicephaloides polyorchis Groschaft and Tenora 1978 (Digenea: Pronocephalidae) from the green turtle Chelonia mydas in Costa Rica
}

\author{
M. SANTORO ${ }^{1 *}$, P. BRANDMAYR ${ }^{1}$, E. C. GREINER ${ }^{2}$, J. A. MORALES ${ }^{3}$, B. RODRÍGUEZ-ORTÍZ ${ }^{4}$
}

\author{
${ }^{1}$ Dipartimento di Ecologia, Università della Calabria, Arcavacata di Rende, Cosenza, Italy, \\ *E-mail: marisant@libero.it,mariosantoro1@gmail.com; ${ }^{2}$ Department of Infectious Diseases and Pathology, \\ College of Veterinary Medicine, University of Florida, Gainesville, Florida $32611 ;{ }^{3}$ Departamento de Patología, \\ Escuela de Medicina Veterinaria, Universidad Nacional, Heredia 3000, Costa Rica; ${ }^{4}$ Laboratorio de Helminthología, \\ Facultad de Microbiología, Universidad de Costa Rica, San Pedro, Costa Rica
}

\begin{abstract}
Summary
Charaxicephaloides polyorchis Groschaft and Tenora, 1978 is redescribed on the basis of specimens collected from the stomach of green turtles Chelonia mydas in Costa Rica. Our specimens are consistent with the original description which was based on four flukes from the same host species from the northwest coast of Cuba. Our redescription provides a new range of variations and adds new information on this species. This represents only the second record of $C$. polyorchis in green turtles.
\end{abstract}

Keywords: Charaxicephaloides polyorchis; Pronocephalidae; green turtle; Chelonia mydas; Costa Rica

\section{Introduction}

Digenetic trematodes belonging to the Pronocephalidae Looss, 1899 have been described or recorded from several aquatic hosts including marine fish, birds, Galapagos marine iguanas, freshwater, and marine turtles. The green turtle Chelonia mydas Linnaeus, 1758 is parasitized by a wide range of digenetic trematodes dominated by pronocephalids (Pérez-Ponce de León et al., 1995; Santoro et al., 2006). Digenetic trematodes collected during a parasitological survey performed on green turtles at Tortuguero National Park, Costa Rica by Santoro et al. (2006) included many specimens of the pronocephalid Charaxicephaloides polyorchis Groschaft \& Tenora, 1978. Because the original description of this species was incomplete and based on only 4 flukes, herein we redescribe $C$. polyorchis, providing new information on this trematode.

\section{Material and Methods}

From June through September in 2003 and 2004 at Tortuguero National Park $\left(10^{\circ} 32^{\prime} 27^{\prime \prime} \mathrm{N}, 83^{\circ} 29^{\prime} 59^{\prime \prime} \mathrm{W}\right.$ - 10 $10^{\circ} 21^{\prime}$ $\left.17^{\prime \prime} \mathrm{N}, 83^{\circ} 23^{\prime} 29^{\prime \prime} \mathrm{W}\right)$, on the north Caribbean coast of Costa Rica, 40 nesting green turtles (curved carapace length ranged from 92 to $111 \mathrm{~cm}$ ) found dead on the beach, were necropsied. Gastrointestinal tracts which included the oesophagus, stomach, and intestine were examined for parasites following methods of Greiner et al. (1980). Flukes were fixed in AFA (alcohol-formalin-acetic acid) or $70 \%$ ethanol, stained with Mayer's acid carmine, mounted in Canada balsam and studied by light microscopy. Measurements are reported in micrometers (unless otherwise stated) with the mean and standard deviation followed by the range in parentheses. Prevalence and intensity were recorded according to definitions by Bush et al. (1997). Figure 1 was drawn with the aid of a camera lucida. Specimens were deposited in the Colección Helmintológica de Costa Rica (CHCR), Universidad de Costa Rica, San Pedro, Costa Rica, and the Harold W. Manter Laboratory of Parasitology (HWML), Nebraska State Museum, Lincoln, Nebraska.

\section{Results}

Charaxicephaloides polyorchis Groschaft \& Tenora 1978 (Fig. 1).

Description based on 35 mature specimens. Body elongate, $5.5 \pm 0.7(4.6-6.2) \mathrm{mm}$ long by $1.6 \pm 0.2(1.2-2) \mathrm{mm}$ wide, thick, with 2 conical projections at posterior extremity. Tegument unspined. Colour of live specimens is yellow to cream with black streaks on extremities and back of body (Fig. 2). Oral sucker well developed, subterminal, circular to ovoid, $590 \pm 101(433-714)$ long by $624 \pm 91$ (484 - 765) wide. Cephalic collar reniform, well developed, $1.6 \pm 360(0.8-2) \mathrm{mm}$ wide. Oesophagus muscular $510 \pm 126(288-649)$ long, bifurcating immediately to posterior margin of cephalic collar. Ceca well developed reaching posterior of body and with large transverse diverticula laterally and medially throughout their entire length. Testes numerous, in middle third of body between anterior end of cirrus sac and anterior limit of vitelline 


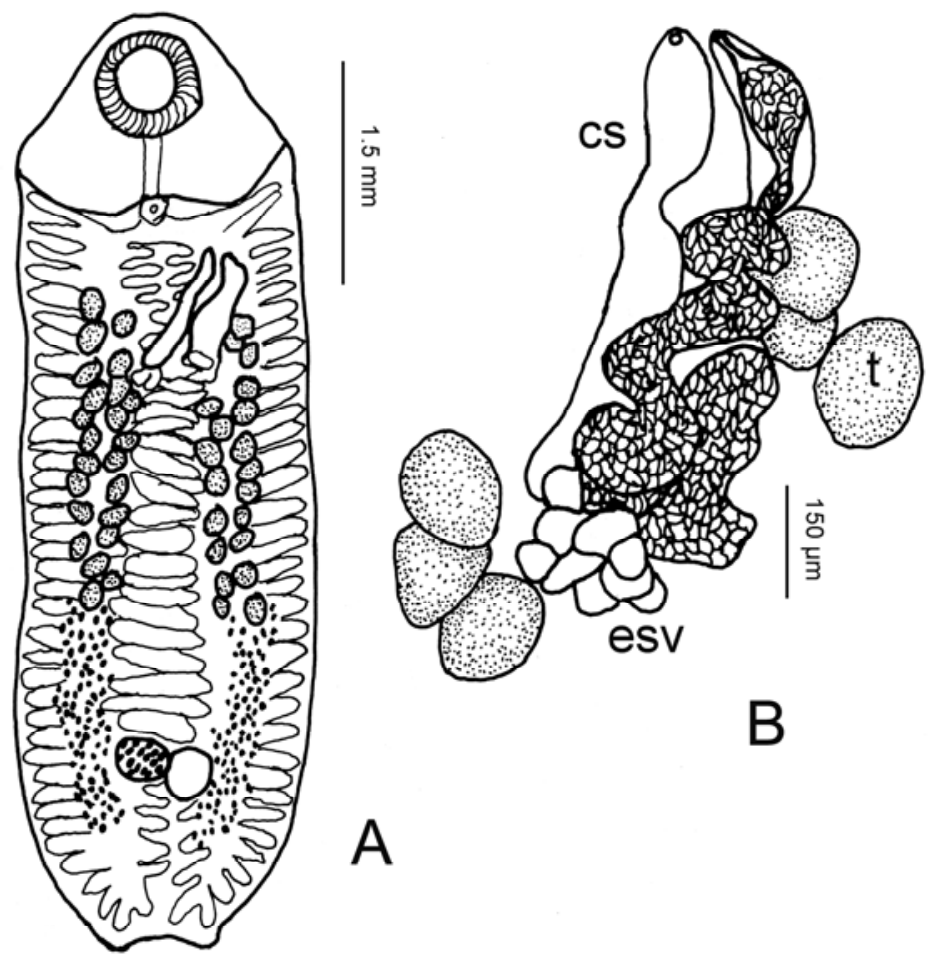

Fig. 1. Charaxicephaloides polyorchis. A, ventral view; B, terminal genitalia. Abbreviations: cs - cirrus sac; esv - external seminal vesicle; $\mathrm{t}$ - testis

follicles, from 14 to 24 on left side and from 21 to 26 on right side, smooth, ovoid to rounded, arranged on each side of body lateral to uterus in irregular double rows, not separated by uterine loops. Left testes $(\mathrm{n}=40) 158 \pm 36$ $(103-237)$ long by $148 \pm 29(103-206)$ wide. Right testes $(\mathrm{n}=40) 153 \pm 25(112-206)$ long by $143 \pm 33(102$ - 206) wide. Cirrus sac fusiform $639 \pm 138$ (463 - 875) long divided into 2 parts by narrowing in middle; genital pore sinitral. Coiled external seminal vesicle posterior to base of cirrus sac. Vitellaria in lateral fields consisting of minute and variable sized follicles extending for $25-30 \%$ of body from near posterior testis to about $10 \%$ of body length from posterior of body. Vitelline follicles on left side $(\mathrm{n}=40) 40 \pm 10(27-65)$ long by $41 \pm 11(27-67)$ wide. Vitelline follicles on right side $(\mathrm{n}=40) 37 \pm 10(22-$ $57)$ long by $38 \pm 10(24-62)$ wide. Ovary smooth, round to oval $252 \pm 41(196-309)$ long by $259 \pm 54(196-350)$ wide, in posterior $25 \%$ of body on right side of midline. Mehlis' gland, irregular to ovoid, $248 \pm 43$ (175 - 309) long by $285 \pm 71(175$ - 381) wide, sinistral, opposite ovary. Laurer's canal not seen. Uterus preovarian, intercecal, extending from anterior margin of ovary to posterior limit of cirrus sac. Eggs numerous $(n=40)$ oval $34 \pm 4(24$ - 49) long by $16 \pm 2(12-22)$ wide, with braided bundle of polar filaments on each end. Egg polar filaments $(n=3)$ $290 \pm 21(270-310)$ long. Excretory vesicle large, $449 \pm$ $119(270-594)$ long by $103 \pm 18(81-135)$ wide, placed between ends of ceca.

\section{Taxonomic Summary}

Host: Green turtles Chelonia mydas Linnaeus, 1758.

Site of infection: Stomach.

Locality and collection dates: Tortuguero National Park $\left(10^{\circ} 32^{\prime} 27^{\prime \prime} \mathrm{N}, 8^{\circ} 29^{\prime} 59^{\prime \prime} \mathrm{W}-10^{\circ} 21^{\prime} 17^{\prime \prime N}, 83^{\circ} 23^{\prime} 29^{\prime \prime} \mathrm{W}\right)$, Limón Province, on the northeast Caribbean coast of Costa Rica; June to September 2003 and 2004.

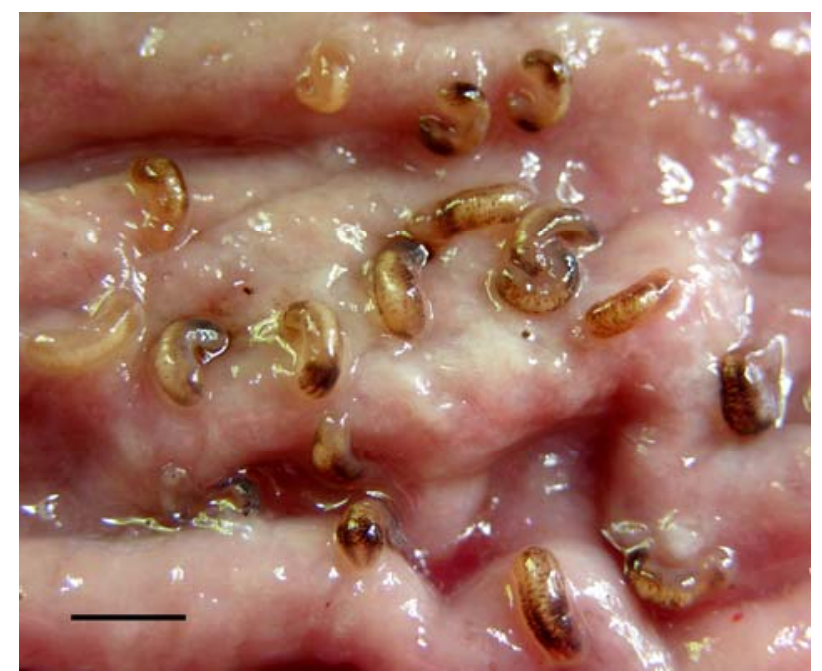

Fig. 2. Specimens of Charaxicephaloides polyorchis on the gastric mucosal surface in a Chelonia mydas. Bar $=2 \mathrm{~mm}$. 
Vouchers deposited: CHCR 169; CHCR 171/180; HWML 48203/48204.

Prevalence and intensity: Eleven of 40 hosts infected (27.5 $\%$ ). Mean intensity, 28; range, $6-127$.

Additional record: Chelonia mydas in the northwest coast of Cuba (Groschaft \& Tenora 1978).

\section{Discussion}

The genus Charaxicephaloides and the species C. polyorchis were created by Groschaft and Tenora (1978) from 4 flukes collected from the stomach (?) of a green turtle caught on the north west coast of Cuba. Charaxicephaloides polyorchis is the only species in this genus. Within Pronocephalidae, Charaxicephaloides differs from Charaxicephalus and Desmogonius by having testicular follicles arranged in an irregular double rows not separated by uterine coils (Groschaft \& Tenora, 1978; see also Blair, 2005).

Our comparison with flukes of Groschaft and Tenora (1978) was based on their original description as their specimens were not available for examination from the Collection of the Institute of Parasitology, Czechoslovak Academy of Science in Prague. Our specimens have ceca with more developed transverse diverticula throughout their entire length, extending from lateral limit to the median line; the cirrus sac is divided in 2 parts by an evident narrowing while in the original description a constriction (not mentioned in the text) seems to be rather close to the genital pore; Mehlis' gland is located on the left side of the midline of body, opposite the ovary, while in the original description it is medial and sub-ovarian. Finally, all our specimens show the genital pore on the left of the midline. In the drawing of Groschaft and Tenora (1978) the genital pore is on the right of the midline. Their drawing was probably drawn from the ventral side, but this is not explicitly stated by authors. Reversal of the position of internal organs is not uncommon in many species of digenetic trematodes. In a related species Desmogonius desmogonius, the genital pore can be located on either side of the midline (Coil \& Reid, 1965). Despite the differences noted above, we place these specimens within $C$. polyorchis (being only the second record of this species) until more specimens are available for study from other geographical areas, preferably including specimens from the type locality.

\section{Acknowledgements}

We are grateful to the Tortuguero Conservation Area and the Park Rangers for their logistic support to facilitate sampling on the beach. Research activities at the Tortuguero National Park were conducted-under permission 091-2003/2004-OFAU from Ministry of Environment and Energy, and the National System of Conservation Areas of Costa Rica. Garry Foster reviewed the early draft of the paper and offered constructive comments for its improving.

\section{References}

BLAIR, D. (2005): Family Pronocephalidae Looss, 1899. In A. Jones, R. A. Bray, D. I. Gibson (Eds): Keys to the Trematoda, Vol. 2. CAB International and The Natural History Museum, London, $361-380$

Bush, A. O., Lafferty, K. D., Lotz, J. M., Shostak, A. W. (1997): Parasitology meets ecology on its own terms: Margolis et al. revisited. J. Parasitol., 83: 575 - 583

CoIL, W. H., REID, W. A. (1965): Desmogonius desmogonius Stephens, 1911 (Pronocephalidae: Digenea), a redescription with observation on egg filament formation. Z. f. Parasitenkunde 25: 506 - 509

Greiner, E. C., Forrester, D. J., JACOBSON, E. R. (1980): Helminths of mariculture-reared green turtles (Chelonia mydas) from Grand Cayman, British West Indies. Proc. Helminthol. Soc. Wash., 47: $142-144$

Groschaft, J., TENORA, F. (1978): Charaxicephaloides polyorchis Gen. Nov., Sp. Nov. (Trematoda: Charaxicephalinae) from Chelonia mydas mydas (Testudinata) in Cuba. Vestnik Cs. Spol. Zool., 42: 108 - 111

PÉrez-Ponce De León, G., BrooKs, D. R. (1995): Phylogenetic relationship of the genera of the Pronocephalidae Looss, 1902 (Digenea: Paramphistomiformes). J. Parasitol., 81: $267-277$

Santoro, M., Greiner, E. C., Morales J. A., RoDríguez-OrTíz, B. (2006): Digenetic trematode community in nesting green sea turtles (Chelonia mydas) from Tortuguero National Park, Costa Rica. J. Parasitol., 92: $1202-1206$

ACCEPTED APRIL 30, 2009 